\title{
Social Clause in Trade Agreements and China's Experience
}

\author{
Haoqian Chen \\ Law School, University of Warwick, Coventry, UK \\ Email: haoqian.chen@warwick.ac.uk
}

Received 15 December 2014; accepted 29 December 2014; published 13 January 2015

Copyright (C) 2015 by author and Scientific Research Publishing Inc.

This work is licensed under the Creative Commons Attribution International License (CC BY). http://creativecommons.org/licenses/by/4.0/

(c) (i) Open Access

\begin{abstract}
The debate that whether inserting "social clause" into trade agreements is justified has been heated recently. This article illustrates how the arguments historically put forward to justify the use of the "social clause", and how effective this mechanism can be for ensuring that work-related social issues are appropriately taken into account in the operation of international trade arrangements in the context of increasingly integrated economy.
\end{abstract}

\section{Keywords}

Social Clause, Labour Standards, Free Trade Agreement

\section{Introduction}

The competition in the international market where free movements of goods and cultural communication are significantly common is becoming increasingly fierce as the emergence of transnational corporations (TNCs) resulted from the current wave of globalization. Those TNCs strive to shift their manufacturing factories offshore to some developing countries, such as India, Vietnam, China or Bangladesh (Hepple, 2005), drawing on the much cheaper labour to enjoy the cost advantage in global competition, due to the gradually opening policies and the reduced transportation cost by ever-developing technology (Palley, 2004). This phenomenon leads to "race to the bottom", which indicates that TNCs pursue the maximum profits by hiring low-wage employees. However, the "race" is not only claimed to be unfair to those companies that do not join the game but also regarded as violation of labour rights of workers. The "social clause" is proposed to address this malignant price competition, which has been controversial hitherto, imposing minimum standards within the framework of liberalization of trade. This article tries to argue that the social clause is justified and effective in current mechanism despite some problems raised by opponents.

This article is divided into five sections. The introduction sketches the background, the issue, and the signi- 
ficance of this study. The articulated definition of social clause and the historical arguments put forward to justify the use of "social clause" are presented in the Section 2. With respect of economic and moral elements, particular emphasis is placed on the debate on "social clause" from the perspectives of developing and developed countries. This article then evaluates critically how effective the social clauses are in US and EU trade agreements in Section 3. In Section 4, examination is given to the prospect of social clause in China's free trade agreements. In Section 5, this article concludes by supporting the effect of the social clause.

\section{Justification of Social Clause: From a Historical Perspective}

Social clause was initially proposed as an instrument to response "social dumping" defined as substantial export from developing countries in which labour costs are relatively low to developed countries in which production costs are comparetively much higher (Hurtado \& Argerey, 2008). However, the misrable wages and deplorable working conditions result in the developed countries' trendency to import low-cost goods impinging on domestic industry market, causing unemployment and affecting the interest of domestic workers, other than infringement alien workers' labour rights, thereby being in urgent need of resolution (Servais, 2009). The aim of social clause is to supplement international trade agreements with minimum or equitable labour standards, preventing the unrational price advantadges formed by squeezing cheaper labour (Servais, 2009).

Dating back to the creation of international trade system in 1947, in United Nations Conference on Trade and Employment, unfair labour conditions, especially in production for export had been realized and feasible action was requested to eliminate such conditions ${ }^{1}$. The debate on the justification of the connection between international trade and labour standards has been heated for a long time since then.

"Protectionism" claims that the social clause is an instrument put forward by industrialised countries to raise tarrif barriers blocking importion with competitive price advantadges from developing countries, thereby guaranteeing the market of the domestic companys (Servais, 1989). However, in 1956, a study about harmonising labour protection ("Ohlin Report") was conducted by ILO (International Labour Organisation). In this report, experts found states with better social protection and higher wages would not be affected by the unfair competition from states with low wages in the long term, albeit possibly affected in short term, because of exchange rates after analysing the European market ${ }^{2}$.

On the one hand, some developing countries argues that massive export by virtue of low wages and comparative prices could stimulate the economic and social development, without developed technologies and abundant captial in developed countries, and therefore whether having lower labour costs should be contingent (Blanchard, 1980). On the other hand, Servais contends that apart from labour costs, the final price of goods is influenced by other factors, such as occupational diseases and accidents, possible maintainance on equipments (Andreoni, 1986) or rent expense, which leads to the difficulty of evaulation on the actual influence of social clause on final prices (Servais, 1989). Morever, some developed countries, such as US, adoptspecial and differential treatment to those developing countries which have satisfying labour protection to facilitate their exports (Jackson, 1997).

By analyzing data in India from 2005 to 2014, the Figure $1^{3}$ demonstrates that raising minimum wages does not reduce the exports. Nor does it boost the labour cost that yet remains unchanged roughly. On the contrary, it facilitates domestic consumption and promotes the exports which both experience a general escalating trend which also contradicts the developing countries' standing.

Although Dorman, in 1995, says that the increase of workers' wages are offset by unemployment in the light of data analysis (Dorman, 1995). Kapstein opposes that the most causes of unemployment were not only the increasing import from Asian countries where no minimus labour standards were promulgated but also technological innovation which leaded to the fact that many repetitive work was replaced by more efficiency machines (Kapstein, 1996).

Palley (2004) claims that raising minimum labour standards and improve working conditions is "win-win" from an macroeconomic perspective. Maintaining low-wages production will make developing countries pursue a export-led growth path, thereby forming a vicious cycle in which export in these countries increases dramatically by reason of the declining prices which these countries chase to gain larger comparative advantage in the "race to the bottom". Consequently, developing countries become much more dependent on export and supply will exceed demand (Palley, 2004). Nevertheless, raising minimum labourstandards will enhance the consuming

\footnotetext{
${ }^{1}$ United Nations Conference on Trade and Employment: Final act and related documents (Havana, 1948), Article 7.

${ }^{2}$ ILO: Social aspects of European economic co-operation (Geneva, 1956: p. 91).

${ }^{3}$ Source information is available online in the country statistics application and in Excel data extracts.
} 


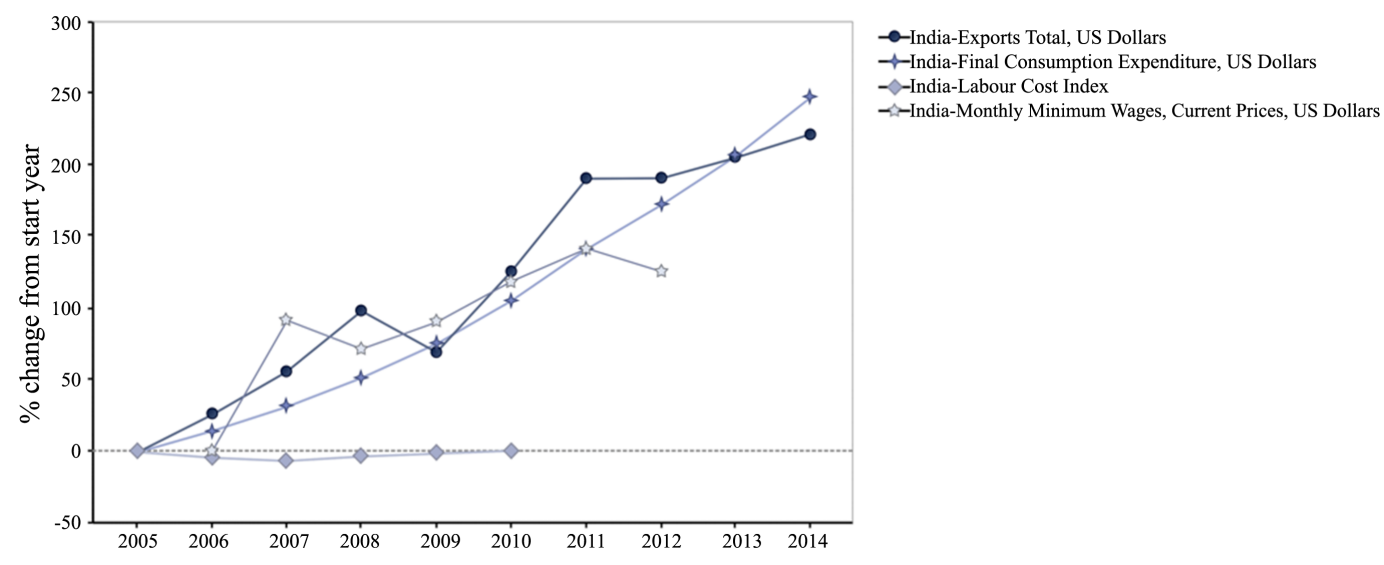

Figure 1. Exports total, final consumption expenditure, labour cost index and monthly minims wages in India.

capacity of domestic market reducing the dependence on export.

The historical discussion on justification of social clause shows the competition advantages obtained by ignoring miserable wages have negative impact on domestic and international level and hence inserting minimum labour standards is justified to strengthen the protection of workers and economic stability.

\section{To What Extent Social Clause Operates in International Trade Agreement}

\subsection{US-Jordan FTA and Other US FTAs}

Compared with the previous agreements including labour rights in side agreements, such as the North American Agreement on Labour Co-Operation (NAALC) ${ }^{4}$ signed in 1993, the Article $6^{5}$ in the US-Jordan FTA signed on 24 October 2000 is the first inclusion of labour rights in main text (Hepple, 2005).

The main feature of US-Jordan FTA is the nature of soft with respect of labour. "Strive to ensure" in Article 6 indicates the non-binding obligations to enforce labour principles set forth in parafigure 6, such as "acceptable

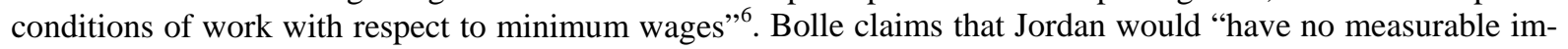
pacts on total US exports, total US imports, US production, or US employment" (Bolle, 2001). However, the Figure $2^{7}$ shows that from 2000 to 2005, both the exports and ADP (Automatic Data Processing) employment witnessed a significant increase indicating the improvement of employment condition.

Apart from it, the parties "reaffirm their obligations as members of the ILO and their commitments under the ILO Declaration on Fundamental Principles and Rights at Work and its Follow-Up", , which implicates that this article is included in ILO framework in terms of labour issues in this agreement. Although some core labour standards including freedom of association, rights of collective bargaining, forced labour, employment discrimination and abolition of child labour, are governed by WTO rules, social clauses in trade agreements should not be covered in the scope of WTO governance for the nature of labour and the "hard" mechanism of WTO.

The words, "labour is not a commodity", set forth in the Article I of ILO Declaration of Philadelphia which was annexed to the Constitution of $\mathrm{ILO}^{10}$, define the nature of labour. WTO, however, handles the trade rules and agreements between nations eliminating tariffs or other trade barriers ${ }^{11}$. It is arguably that incorporating rules of labour, which pertains to the non-commodity category, into such organization in charge of trade is not suitable. ILO, a specialized organization of which objectives are to pursue better working conditions and social justice $^{12}$, is radically more relevant with social clause including minimum labour standards.

\footnotetext{
${ }^{4}$ See NAALC Annex 1: Labour Principles.

${ }^{5}$ See US-Jordan FTA Article 6: Labour.

${ }^{6}$ See US-Jordan FTA Article 6, Para 6.

${ }^{7}$ Source: http://www.tradingeconomics.com, US Bureau of Labour Statistics.

${ }^{8}$ See US-Jordan FTA: Art 6, Para 1.

${ }^{9}$ ILO Declaration of Philadelphia, declaration concerning the aims and purposes of the International Labour Organization.

${ }^{10}$ ILO: Constitution of the International Labour Organization and Standing Orders of International Labour Conference.

${ }^{11}$ The WTO in brief http://www.wto.org/english/thewto_e/whatis_e/inbrief_e/inbr00_e.htm accessed 25 November 2014.

${ }^{12}$ See the Preamble in Constitution of the International Labour Organization, "whereas universal and lasting peace can be established only if it is based upon social justice".
} 
UNITED STATES EXPORTS | UNITED STATES ADP Employment Change

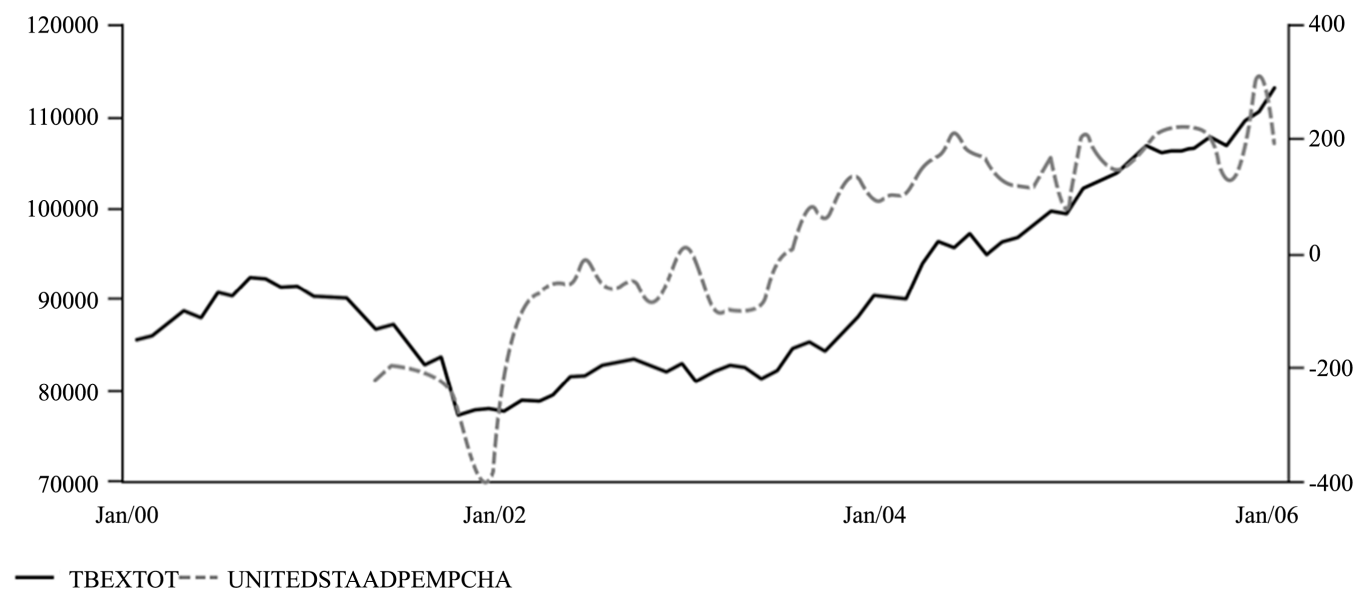

Figure 2. Exports and ADP employment change in United States.

The Joint Committee, which is "established to supervise the proper implementation of this agreement and to review the trade relationship between the parties" ${ }^{\prime 3}$, is another characteristic of this agreement. The committee "shall convene at least once a year in regular session in order to review the general functioning of the agreement”. Although the supervisory article is general without reference to labour issues, the Figure $3^{14}$ illustrates that the labour force participation rate in both US and Jordan declined steadily notwithstanding some fluctuations from 2000 to 2006, which means that forced labour has been controlled effectively.

Six other FTAs were signed including US-Australia, US-Bahrain, US-Chile, US-Morocco, US-Singapore and Central American Free Trade Agreement respectively (Siroën, 2013), which resemble to the US-Jordan FTA despite the main difference on the existence of an independent tribunal in which dispute can be settled and a fine of a maximum of 15 million dollars a year may be imposed in the event of incompliance (Siroën, 2013). In addition, these FTAs explicitly included ILO's Declaration (1998) of which principles has been proliferated (Alston, 2004).

\subsection{EU Trade Agreements}

The social clauses in previous European Union (EU) agreements are implicit including "human rights" or "democratic principle" 15 which is respected as "essential elements" in bilateral trade agreements (Clapham \& Martignioni, 2006), rather than "labour standards". Suspension or termination is entitled to EU in the event of flagrant violation of human rights (Fierro, 2003). Until 2000, the initial addition of a clause explicitly regarding to labour standards occurred in the Cotonou Partnership Agreement (CPA) (Hepple, 2005), where Article 50 concerning "Trade and Labour Standards" states that "the parties reaffirm their commitment to the internationally recognized core labour standards, as defined by the relevant International Labour Organization (ILO) Conventions”16.

The first feature of CPA is the emphasis on respect for "all human rights"17, which is regarded as an "integral

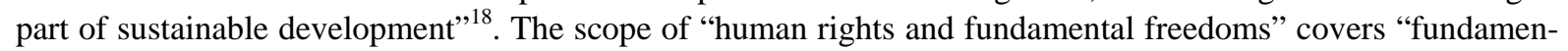
tal social rights" which are not defined explicitly. However, the scope may be consistent with the preamble where parties are "anxious to respect basic labour rights, taking account of the principles laid down in the relevant conventions of the International Labour Organization"19.

Second, the purpose and effect of Article 50 is controversial. Hepple asserts "Article 50 is merely declaratory"

\footnotetext{
${ }^{13}$ See US-Jordan FTA: Art 15, Para1.

${ }^{14}$ Source information is available online in the country Statistics application and in Excel data extracts.

${ }^{15}$ See Mauritius Agreement of 1995 and ACP-EC Partnership Agreement: Article 9.

${ }^{16}$ See Cotonou Agreement: Article 50.

${ }^{17}$ Cotonou Partnership Agreement: Art 9.

${ }^{18}$ Ibid, Art 9 (1).

${ }^{19}$ Ibid, the Preamble.
} 


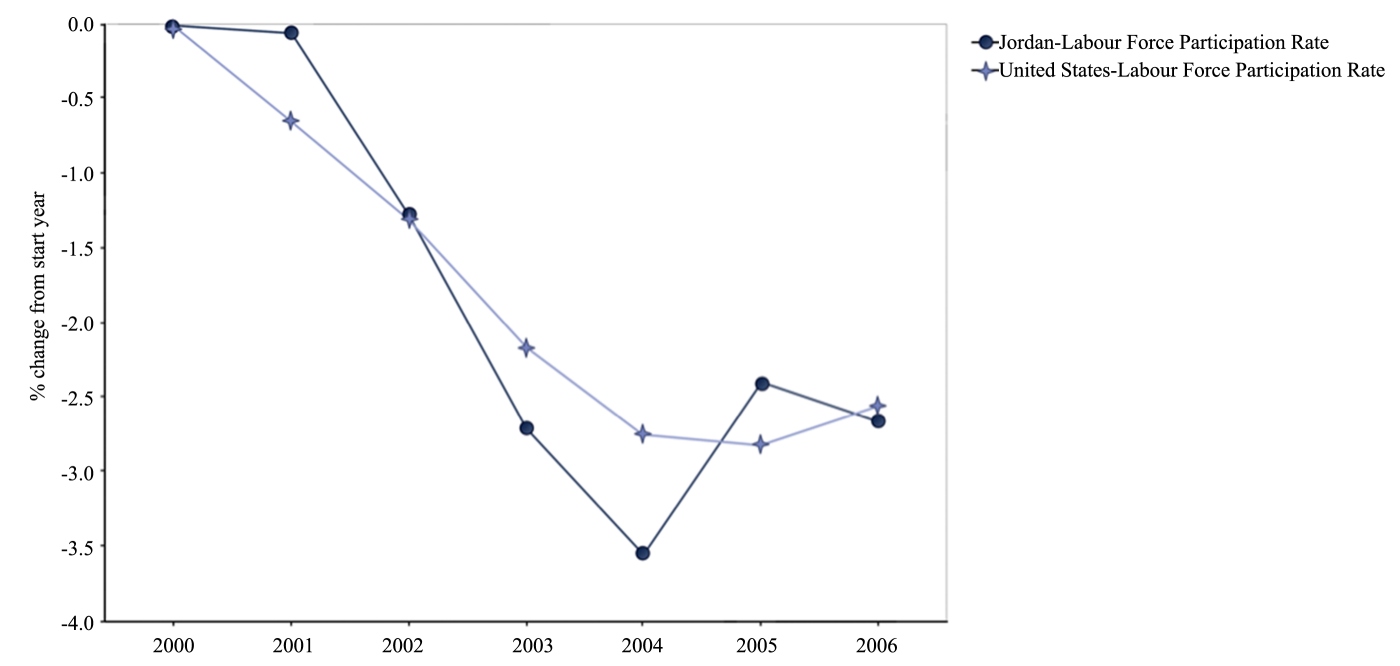

Figure 3. Labour force participation rate in Jordan and United States.

because "core labour standards" are embraced by the international instruments ${ }^{20}$ listed in the preamble (Hepple, 2005). But Kenner contends that it is "more than a mere declaration". Instead of understanding Article 50 separately, it should be put in the context of the whole agreement where the soft commitments of parties who have ratified ILO conventions are transformed to binding obligations for compliance with ILO conventions (Kenner, 2011).

The third feature is political dialogue of which objectives are to "exchange information" 21 and facilitate the compliance of this agreement, stipulated in Article 8. In terms of "human rights", it focuses on "a regular assessment of the developments concerning the respect for human rights" 22 . In the event that one party violates the obligations regarding human rights albeit conducting political dialogue, consultation introduced by Article 96 can be held as remedy to resolve the condition ${ }^{23}$. But in case that the parties cannot reach an agreement on an acceptable solution, appropriate measures ${ }^{24}$, which should be consistent with international law conforming with principles of necessity proportionality and non-force (Elagab, 1988), can be invoked.

\section{The Prospect of Social Clause in China's Free Trade Agreements}

\subsection{Why Do China Need Free Trade Agreement?}

After deciding to "to adopt a free trade area strategy and enhance bilateral and multilateral economic cooperation”25 in 2007, China has concluded FTAs with Hong Kong, Macau, Chile, Pakistan, ASEAN, New Zealand, Singapore ${ }^{26}$ and so forth. There are three main reasons for signing these FTAs.

First, from an economic perspective, these FTAs indeed stimulate economic development significantly. Take China-Chile FTA signed in October 2006 as a case, in 2007 bilateral trade volume reached 14.7 billion dollars comprising 10.3 billion dollars in import from Chile and 4.4 billion dollars in export to Chile and the increasing rate was from $20 \%$ before the implementation to $65 \%$ in the following year ${ }^{27}$.

\footnotetext{
${ }^{20}$ They are "the principles of the Charter of the United Nations, the Universal Declaration of Human Rights, the conclusions of the 1993 Vienna Conference on Human Rights, the Covenants on Civil and Political Rights and on Economic, Social and Cultural Rights, the Convention on the Rights of the Child, the Convention on the Elimination of all forms of Discrimination against Women, the International Convention on the Elimination of all forms of Racial Discrimination, the 1949 Geneva Conventions and the other instruments of international humanitarian law, the 1954 Convention relating to the status of stateless persons, the 1951 Geneva Convention relating to the Status of Refugees and the 1967 New York Protocol relating to the Status of Refugees".

${ }^{21}$ Cotonou Partnership Agreement: Art 8.

${ }^{22} \mathrm{Ibid}$.

${ }^{23}$ Ibid, Art 96.

${ }^{24}$ Ibid.

${ }^{25} \mathrm{Hu}$ Jintao's Report on the Party Congress, XINHUA, Oct.24, 2007 (in Chinese), at http://news.xinhuanet.com/newscenter/2007-10/24/content_6938568_4.htm.

${ }^{26}$ See http://fta.mofcom.gov.cn/english/index.shtml.

${ }^{27}$ See http://fta.mofcom.gov.cn/chile/chile_xiedingshishi.shtml.
} 
Second, pursuant to geopolitical consideration, China needs to cope with political relations with neighbors and enough support from them to compete Japan (Wang, 2011). Concluding FTAs is a best choice for China to share common interest and develop with neighbors together, which provides more opportunities with China to have not only economic but also political communication with them.

Third, notwithstanding China joined WTO, China is still treated as a nonmarket economy so China attempts to accomplish the same goal by conclusion of $\mathrm{FTAs}^{28}$ where other parties recognize China as a market economy (Janow, 2008).

\subsection{The Necessity of Inserting Social Clause into China's Free Trade Agreements}

In concluded FTAs, social clause regarding work-related social issues almost dose not exist albeit the Article 96 in China-Ireland FTA and the Article 13.5 in China-Switzeland FTA, which only write "cooperation on labour and employment" without any substansial labour standards. Nevertheless, "protect the domestic labour force” has already been spelled out in the following FTAs which are Article 102 in China-Costa, Article 78 ChinaSingapore FTA and Article 126 China-New Zealand FTA respectively.

Such incorporation stimulates the domestic protection of workers forced to work. Although China does not ratify Abolition of Forced Labour Convention (No. 105), Article 20(e) in GATT ${ }^{29}$ and Article 8 point 3(c) in International Covenant on Civil and Political Rights ${ }^{30}$ signed by China in 1998 both refer to the forced labour issue. The re-education through labour (Laojiao) viewed as anarbitrary administrative penalty violating citizens’ rights of liberty has been completely abolished in November 2013.

However, some FTAs without reference to work-related issues are countering contest and disgreement. For instance, as China-ASEAN FTA concluded, contester claim that China has affected the Indonesia's manufacturing sector negatively due to its cheaper but more productive manpower ${ }^{31}$. China's comparative advantages has become a great threat to other countries and thus social clause regarding labour standards should be inserted into this FTA, which may be a compromising measure to resolve not only the unfair competition but also protect workers' rights.

During the negotiation of China-Japan-Korea FTA, some manufacturing lobbying groups in China declare strong resistance due to the competition with counterparts in both Japan and Korea (Madhur, 2013). Coping with the competition in the context of trade agreements, in case of "race to the bottom" for the competitive price advantages, social clause may be an effective measure to govern such condition.

\subsection{The Capability of Implementing Social Clause Related to Labour Standards in Domestic Labour Law Level}

By observing the implementation in terms of equity and discrimination, this article try to prove that China has the the capability of implementing social clause related to labour standards in domestic labourlaw level. Since China joined WTO in 2001 and ratified two conventions, Equal Remuneration Convention, 1951 (No. 100) and Discrimination (Employment and Occupation) Convention, 1958 (No. 111), some effective measures has been done to address the problems about equity and discrimination in legislation level although some matters still need to be paid attention to.

In terms of equal remuneration, the principle of equal remuneration for equal work has been introduced in Article 11 of Labour Contract Law ${ }^{32}$ and Article 46 of Labour Law ${ }^{33}$. The principle of equal remuneration for men

${ }^{29}$ The General Agreement of Tariff and Trade, Article 20: Subject to the requirement that such measures are not applied in a manner which would constitute a means of arbitrary or unjustifiable discrimination between countries where the same conditions prevail, or a disguised restriction on international trade, nothing in this Agreement shall be construed to prevent the adoption or enforcement by any contracting party of measures: (e) relating to the products of prison labour.

${ }^{30}$ International Covenant on Civil and Political Rights, Article 8 Para 3(a): No one shall be required to perform forced or compulsory labour.

${ }^{31}$ FTA with China "will deal a blow to manufacturing sector”, JAKARTA POST. 2004. World Sources Online.

${ }^{32}$ Labour Contract Law of China, Article 11: Where an employer fails to conclude a written labor contract when the employer put his employee to work, if the remuneration stipulated between the employer and the employee is not clear, the remuneration to the new employee shall conform to the provisions of the collective contract. If there is no collective contract or if there is no such stipulation in the collective contract, the principle of equal pay for equal work shall be observed.

${ }^{33}$ Labour Law of China, Article 46: The distribution of wages shall follow the principle of distribution according to work and equal pay for equal work.
} 
and women manifested by the Article 48 of Constitution Law ${ }^{34}$ also has been attached importance to. However, the Committee of Experts in ILO points out that the "equal pay for equal work" is narrower than the principle of No.100 Convention due to lack of combination of "work of equal value"35.

Regarding discrimination, in Constitution Law, that citizens have equal rights of employment and occupation can be deducted based on Article 33 (Para. 2) ${ }^{36}$ and 42 (Para. 1) 37 $^{37}$ of Constitution Law, even though fundamental right of non-discrimination has not been stipulated directly. Moreover, Article 12 in Labour Law ${ }^{38}$ and Article 3 of the Employment Promotion Law ${ }^{39}$ also identify Prohibited grounds of discrimination. But the distinction between direct and indirect discrimination as well as the definition of indirect discrimination has not been clarified in the legislation ${ }^{40}$. With respect to discrimination based on social origin, Chinese government is making great efforts including the Article 31 of the Employment Promotion Law ${ }^{41}$ to put forward the reform of "Hukou" system ${ }^{42}$ despite the fact that a number of rural migrant workers are still discriminated on employment.

\section{Conclusion}

During the last decade, nations have become more interdependent and international trades have become more frequent due to free or eliminated trade tariff or other trade blocks resulted from bilateral and unilateral trade agreements. To control and govern nations which pursue competitive price advantages by squeezing workers' labour to gain more profits, social clause was introduced into free trade agreements. However, the debate on the justification of social clause has never stopped. Having analyzed the argument from different scholars and data, this article has concluded that social clause should be justified for three grounds, the necessity of protection of labour right, long-term stimulation of economy profits, and prevention of "race to the bottom". Nations should consider labour rights into the management of economic activities in the wave of high voice of protecting human rights. In other words, the initiative value of protecting human rights entails the change of accommodating social clauses into free trade agreements. In US and EU free trade agreements, social clauses where human rights or labour standards are combined with trade not only demonstrate the effective operation of such incorporation but also stimulate "healthy" economic development.

Through China's experience, facing to the obstacle of concluding the free trade agreements under negotiation due to lack of protection of workers' rights, this article shows that it is necessary to introduce social clauses related to labour issues into the framework of free trade agreements because of the economic and political significance of these agreements.

\section{References}

Alston, P. (2004). “Core Labour Standards” and the Transformation of the International Labour Rights Regime. European Journal of International Law, 15, 457-521. http://dx.doi.org/10.1093/ejil/15.3.457

Andreoni, D. (1986). The Cost of Occupational Accidents and Diseases. Geneva: ILO.

Blanchard, F. (1980). International Trade and Employment: The Role of ILO. Seminar on the North-South Diagoue, Autumn.

Bolle, M. J. (2001). US-Jordan Free Trade Agreement. Washington DC: Congressional Research Service.

Clapham, A., \& Martignioni, J. B. (2006). Are We There Yet? In Search of a Coherent EU Strategy on Labour Rights and

\footnotetext{
${ }^{34}$ Constitution Law of China: Article 48: The state protects the rights and interests of women, applies the principle of equal pay for equal work for men and women alike and trains and selects cadres from among women.

${ }^{35}$ Observation (CEACR) adopted 2012 on Equal Remuneration Convention (No. 100) China, $102^{\text {nd }}$ ILC session (2013).

${ }^{36}$ Constitution Law of China, Article 33: All citizens of the People's Republic of China are equal before the law. Every citizen enjoys the rights and at the same time must perform the duties prescribed by the Constitution and the law.

${ }^{37}$ Constitution Law of China, Article 42: Citizens of the People's Republic of China have the right as well as the duty to work.

${ }^{38}$ Labour Law of China, Article 12: Labourers shall not be discriminated against in employment, regardless of their ethnic community, race, sex, or religious belief.

${ }^{39}$ Employment Promotion Law of China, Article 3: workers seeking employment shall not be subject to discrimination based on factors such as ethnicity, race, sex, religious belief, etc.

${ }^{40}$ Direct Request (CEACR) adopted 2009 on Discrimination (Employment and Occupation) convention (No. 111) China, 99 ${ }^{\text {th }}$ ILC session (2010).

${ }^{41}$ Employment Promotion Law of China, Article 31: Rural workers who go to cities in search of employment shall enjoy labor rights equal to those of urban workers. It is prohibited to set discriminatory restrictions against rural workers seeking employment in cities.

${ }^{42}$ Direct Request (CEACR) adopted 2012 on Discrimination (Employment and Occupation) convention (No. 111) China, 102 ${ }^{\text {nd }}$ ILC session (2013).
} 
External Trade. In V. Leary, \& D. Warner (Eds.), Globalization and International Institutions, Labour Rights and the EU, ILO, OECD and WTO (pp. 233-311). Leiden: Martinus Nijhoff Publishers.

Dorman, P. (1995). Policies to Promote International Labour Rights: An Analytical Review (pp. 6-7). Lansing: Michigan State University.

Elagab, O. Y. (1988). The Legality of Non-Forcible Counter-Measures in International Law, Oxford.

Fierro, E. (2003). Legal Basis and Scope of the Human Rights Clauses in EC Bilateral Agreements: Any Room for Positive Interpretation. European Law Journal, 7, 41-68. http://dx.doi.org/10.1111/1468-0386.00118

Hepple, B. A. (2005). Labour Laws and Global Trade. Oxford: Hart.

Hurtado, I., \& Argerey, P. (2008). Social Dumping: The Debate on a Multilateral Social Clause. Global Economy Journal, 8 , 1-15. http://dx.doi.org/10.2202/1524-5861.1354

Jackson, J. H. (1997). The World Trading System: Law and Policy of International Economic Relations (pp. 319-322). Cambridge, MA: MIT Press.

Janow, M. E., Donaldson, V., \& Yanovich, A. (2008). The WTO: Governance, Dispute Settlement \& Developing Countries. Huntington, NY: Juris Publishing, Inc.

Kapstein, E. B. (1996). Workers and the World Economy. Foreign Affairs, 75, 23-25.

Kenner, J. (2011). Labor Clauses in EU Preferential Trade Agreements-An Analysis of the Cotonou Partnership Agreement. In K. W. Bagwell, \& P. C. Mavroidis (Eds.), Preferential Trade Agreements: A Law and Economics Analysis (pp. 180209). Cambridge: Cambridge University Press. http://dx.doi.org/10.1017/CBO9780511976445.011

Madhur, S. (2013). China-Japan-Korea FTA: A Dual Track Approach to a Trilateral Agreement. Journal of Economic Integration, 28, 375-392. http://dx.doi.org/10.11130/jei.2013.28.3.375

Palley, T. I. (2004). The Economic Case for International Labour Standards. Cambridge Journal of Economy Society, 28, 2136. http://dx.doi.org/10.1093/cje/28.1.21

Servais, J. (1989). The Social Clause in Trade Agreements: Wishful Thinking or an Instrument of Social Progress. International Labour Review, 128, 423.

Servais, J. (2009). International Labour Law (2nd ed., p. 34). Alphen Aan Den Rijin: Kluwer Law International.

Siroën, J. (2013). Labour Provisions in Preferential Trade Agreements: Current Practice and Outlook. International Labour Review, 152, 85-106. http://dx.doi.org/10.1111/j.1564-913X.2013.00170.x

Wang, G. G. (2011). China’s FTAs: Legal Characteristics and Implications. American Journal of International Law, 3, 493. 
Scientific Research Publishing (SCIRP) is one of the largest Open Access journal publishers. It is currently publishing more than 200 open access, online, peer-reviewed journals covering a wide range of academic disciplines. SCIRP serves the worldwide academic communities and contributes to the progress and application of science with its publication.

Other selected journals from SCIRP are listed as below. Submit your manuscript to us via either submit@scirp.org or Online Submission Portal.
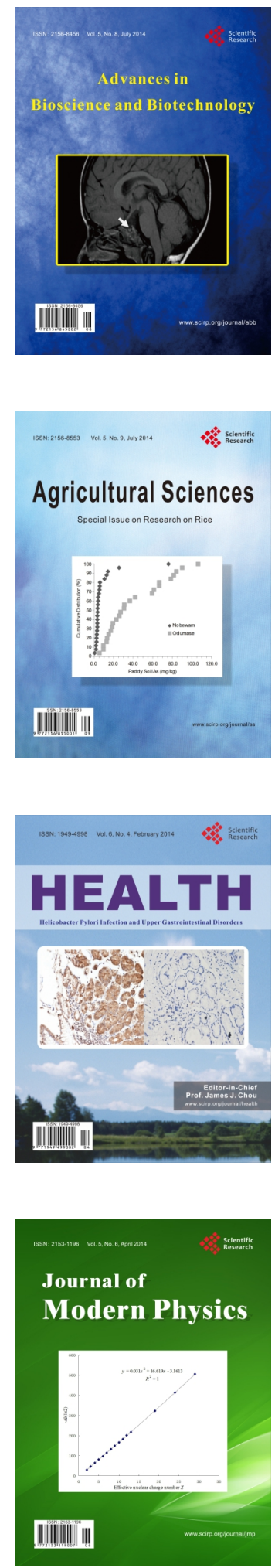
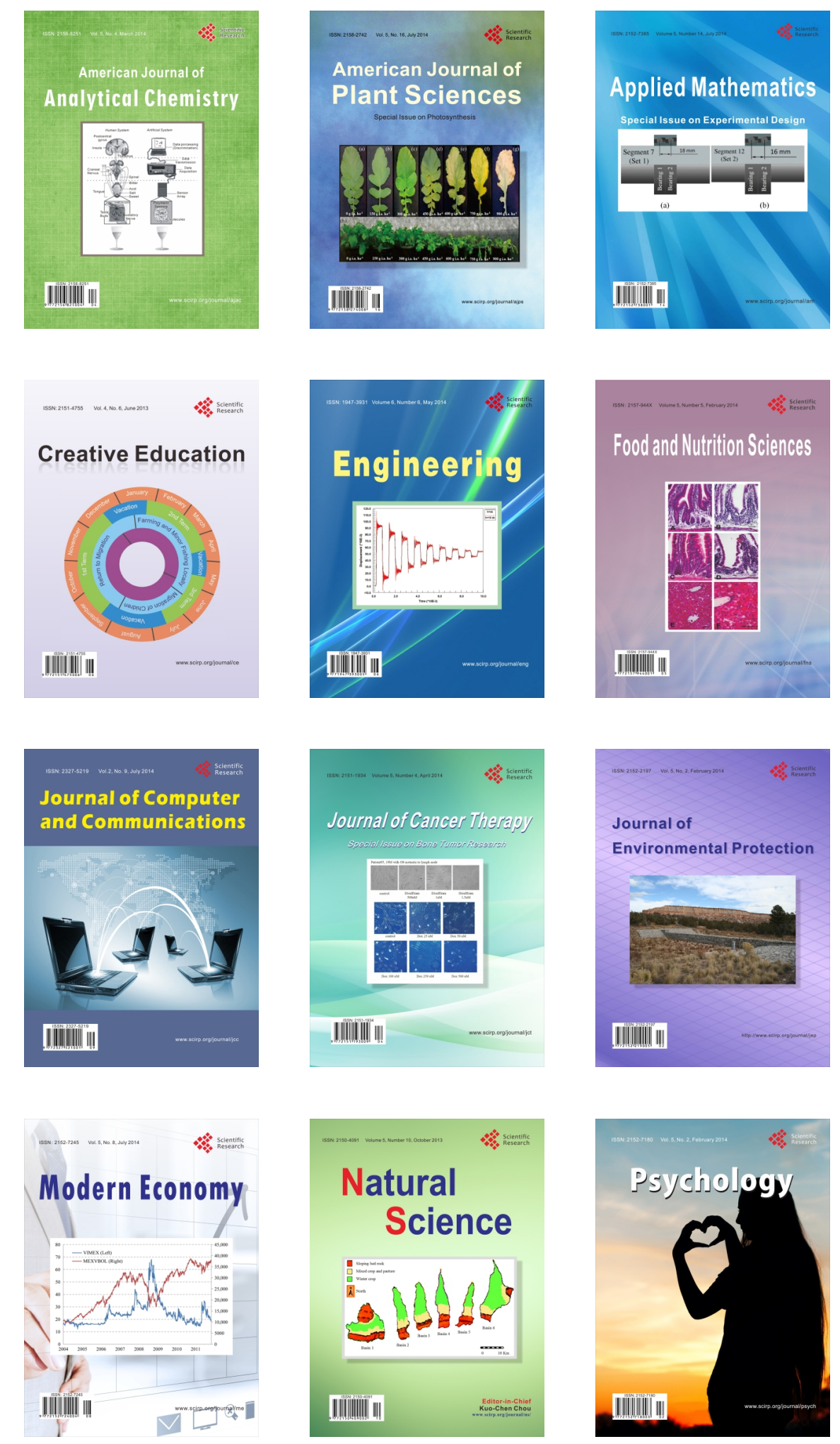